\title{
Provision of the population of Saint Petersburg with green construction objects
}

\author{
Svetlana Ershova ${ }^{1, *}$, Tamara Orlovskaya ${ }^{2}$ \\ ${ }^{1}$ Saint Petersburg State "Research and Design Center of Saint Petersburg Master Plan", Zodchego \\ Rossi St. 1-3, Saint Petersburg, 191023, Russia \\ ${ }^{2}$ Chair of economic safety, Saint Petersburg State University of Architecture and Civil Engineering \\ (SPBGASU), 4, Vtoraya Krasnoarmeiskaya, 190005, Saint Petersburg, Russia
}

\begin{abstract}
The results of studies of greening areas of Saint Petersburg are presented. Differentiation was carried out by indicators of the area of public parks; the area of public green spaces per 1000 inhabitants; share of the area of public green spaces in the district. According to the ranking results, groups of districts have been identified, which make it possible to assess the relative level of greening of the territory of districts and the availability of large green public spaces for the population. Carrying out a study based on the proposed methodology makes it possible to consider the heterogeneity of the complex development of the city territory by various factors. Approbation of the methodology in the context of the administrative districts of Saint Petersburg made it possible to assess the quality of the urban environment by the level of provision of the population with green areas and to set priorities in the green building strategy. The results obtained can be used as a basis for the formation of standards for urban planning of Saint Petersburg, analytical material for adjusting the investment priorities in green building and the formation of programs for the integrated development of city territories.
\end{abstract}

\section{Introduction}

The focus of state policy on improving the quality of the urban environment that provides favorable living conditions, smoothing out uneven territorial development not only in different regions, but also in large megacities, is becoming a priority task of the authorities. Plans to increase the number of Russian cities with a favorable environment are included in the national projects of Russia, and the formation of a comfortable urban environment and the creation of mechanisms for integrated and sustainable development of urban territories is a national priority. Today, the quality of the urban environment is becoming the main indicator of the effectiveness of government agencies and a priority of urban policy.

\footnotetext{
*Corresponding author: S.Ershova@kga.gov.spb.ru
} 
The study of issues related to the provision of recreational areas for the population of cities and the development of green infrastructure is of particular interest for assessing the contribution of urban development policy to improving the competitiveness of the city.

The concept of "city competitiveness" introduced into circulation, interpreted "as the ability to meet the interests of all subjects operating on its territory (residents, business entities, investors, state and municipal authorities), as well as to attract new subjects and investments" [1], allows us to conclude that Russian scientists recognize the influence of the quality of the urban environment, including landscaping, on the competitiveness of the city, safety and comfort of living in it.

Justifying the need of the urban population both in large recreational areas and in territories of public green spaces available for everyday pastime, researchers and experts identify the following main effects of green areas: "reduction of cardiovascular diseases and asthma, increase in physical activity, reduction of obesity, stress relief, relaxation and recovery, reduction of the "urban heat island" effect by $3-4^{0}$, filtration of polluted air" [2].

Uneven development of city territories provokes the creation and development of risk zones associated with the growth of differences in the quality of life of the population, increasing territorial inequality in the degree of provision of favorable living conditions [3]. Alignment of conditions that ensure a minimum level of reference needs of the population, for example, in accessible and safe green infrastructure facilities, to which there is daily, periodic and episodic access, is one of the most important functions of the management system. Based on the above, the need to study the differentiation of megalopolis territories in terms of greening in order to identify existing gaps and develop a strategy for spatial development in order to level out the disparities in the quality of the urban environment and create conditions for a healthy lifestyle in all areas of the city is an urgent task.

\section{Problem statement}

Today, in the context of global changes in the entire way of life and the revision of approaches to the formation of favorable and safe living conditions for the population, changes in the theoretical and methodological provisions for evaluating the effectiveness of development processes are inevitable. In this regard, the statement of L. Y. Hertzberg about the relevance and timeliness of consideration of methodological and methodological problems of assessing the quality of the urban environment as a priority of urban development activity is true $[1,4]$. Green zones of the city, performing the functions of providing conditions for reducing the negative anthropogenic load on the territory and creating conditions for the formation of a safe living environment, provide the urban population with comfortable living. In other words, the quality of the urban environment is largely ensured by the presence of green areas in the fabric of the urban environment.

The research of Russian and foreign scientists noted the priority influence of green zones on the physical and psychological health of the urban population [5-9], which, as the authors rightly noted [10], "...one of the key tasks of urban planning is to ensure the safety of life and create a high-quality urban environment, defined as the ability of the environment to meet human needs."

In research practice, various methods of assessing territorial differentiation are widely used, allowing for comparative analysis and clustering of urbanized territories on various grounds. The use of expert assessments at different stages of assessment - from determining the list of indicators included in the assessment, setting weight coefficients for factors or groups of factors, suggestions for the method of calculating the integral indicator, allows you to get the correct result for conducting a comparative assessment of cities by the level of involvement in the competitive environment, quality of life and quality of the urban 
environment. However, the main methodological problem of applying this method remains the "counterbalance" of the objective and subjective components of expert evaluation.

Therefore, the development of a methodological tool for assessing the differentiation of the level of development of the green infrastructure of inner-city territories, which is characterized by simplicity and the possibility of using available data, is not in doubt.

Objectives of the study can be reduced to the analysis of differentiation of areas of Saint Petersburg the level of sufficiency of public green building, which represents a priority component of the quality of the urban environment, which is the most important indicator of the quality of life for the further development of measures to reduce differences in the level of green infrastructure in local areas.

\section{Theory}

The works of Russian and foreign authors are devoted to the study of various problems related to green construction, smoothing the differences between the achieved quality of the urban environment in various territories of inner-city space, improving the quality of life and comfort of living [1-10]. The problem of greening urban environment is investigated in $[6,11]$, which considers the city as a single ecosystem, the study of hierarchy of urban green spaces in $[10,12]$, the problems of the organization of green areas and their connection with the life support of the population, reviewed in [13] allow us to assert that coloproctectomy approach to solving the problem of disproportions in the development of the city's territory allows to identify "bottlenecks" of green building and to formulate priority directions of further development of green infrastructure.

One of the tools for assessing the quality of the urban environment that is widely used in foreign practice is the methods of ranking/rating indicators.

Such influential companies as A.T. Kearney, The Economist, GaWC, Monocle, Mercer, Eurobarometer conduct rating assessments of global cities based on various indicators [1622]. The accepted foreign assessment methods are based on the results of long-term studies of the quality of life, the quality of the urban environment, and the global nature of cities by outstanding scientists D. Savaggio [23], P. Taylor [24, 25], Peter Hall [26], and others. Ratings compiled on the basis of open statistical data allow you to conduct a comparative analysis of cities, assess the current state of the urban environment and predict the city's ability to maintain its achieved positions. For example, the methodology developed by A. T. Kearney [16,17], which is based on the use of expert methods, is quite transparent, and the list of evaluated indicators allows us to assess the quality of the urban environment and the prospects for its improvement.

Based on rating methods, in 2012, Russian specialists - the Saint Petersburg Institute of territorial planning "Urbanika" together with the Union of architects of Russia and the center for strategic research of Rosgosstrakh-developed methods for assessing the quality of the urban environment [4]. According to Russian scientists, their significant methodological shortcomings were insufficient validity of the choice of evaluation factors and incorrect use of expert assessment methods [4].

Feature selection approaches to the study of the problem of estimation of development of green building and its impact on the quality of the urban environment is the need of objective and subjective components. L. J. Herzberg identifies as an objective component "science-based needs of people in a certain quality of the environment" [1], which should be the basis of standards of quality of the urban environment, differentiated considering socio professional the nature of the city. The problems of the influence of territorial competition on the quality of life, the study of various factors of urban competitiveness, which include the quality and safety of the urban environment, the "health" of the urban environment, including the presence of "green" zones, are also considered in the works of 
foreign researchers [for example, 27]. As the main estimated indicators of urban greening, foreign researchers distinguish: the total area of green areas in the city, the number of green recreational areas, the amount of landscaping in the built-up areas of the city [2]. Russian experts as the main performance indicators used indicators of the amount of green spaces, allowing to appreciate in the city public green areas and the amount of green areas per 1000 inhabitants $[14,15]$. Both indicators reflect the quality of the urban environment and the availability of accessible green areas for everyday recreation and sports. Recreational areas in the form of large forest and Park areas are considered as territories for occasional and periodic use by the population. However, public parks located in close proximity to residential developments should also be considered green areas for everyday use.

Based on the research [2, 4], taking into account the statistical database, the authors identified the following indicators to assess generated in the process of urban activities and characterizing the "health" of the urban environment: the territory of public parks, representing a large landscaped areas not included in residential zones of the city, but located in close proximity to residential development, as well as specific indicators share of green areas in the total area and the proportion of green spaces per 1,000 residents.

In this context, the study of uneven development of the territories of Saint Petersburg using ranking methods to assess the "health" of the urban environment according to the main indicators of green construction is a priority task.

\section{Materials and research methods}

The scientific and theoretical basis of the research is based on the works of leading foreign and domestic scientists in various fields of knowledge [for example, 1, 3, 10, 25, 27]. The study uses published statistical data [28, 29].

The study was conducted for the districts of Saint Petersburg in terms of the area of public parks, the area of public green spaces per 1000 inhabitants, and the share of public green spaces in the district. The methodology for assessing the "health" of urban territories is based on the use of ranking indicators and their equal significance for the assessment.

1 stage of the study, a comparative assessment was conducted of the districts of Saint Petersburg on the parameters describing the density of green spaces and major landscaped areas and recreational areas public parks. Further, based on the results of comparison of indicators, districts were ranked according to the degree of provision of public green spaces and public Park areas.

At the 2nd stage of the study, a comparative assessment of the districts of Saint Petersburg was carried out by the level of greening of the territory of the district and the presence of large green areas of recreational zones in it. According to the results of comparison and ranking of indicators, the level of accessibility of green areas for the population was estimated.

Based on the data obtained, the city districts were grouped according to the degree of balance of indicators of security and accessibility for the population of green zones and the level of greening of territories.

\section{The results of research and their discussion}

The study of differentiation in the development of Saint Petersburg districts was conducted based on the following factors: the area of public parks and relative indicators of the area of green spaces located in the districts of Saint Petersburg [28].

As of the beginning of 2020, there were significant differences in the level of greening of the city's districts in Saint Petersburg [28, 29]. 
Based on the results of monitoring the main characteristics of Saint Petersburg districts [28], the rating of districts was compiled according to the indicators "area of public parks", "area of public green spaces per 1000 people" and "share of public green spaces in the area of the district" (table 1).

Table 1. Rating of Saint Petersburg districts in terms of green infrastructure development*.

\begin{tabular}{|l|c|c|c|}
\hline \multirow{2}{*}{ Area } & \multicolumn{3}{|c|}{ Ranking of district in terms } \\
\cline { 2 - 4 } & $\begin{array}{c}\text { Area of public } \\
\text { parks }\end{array}$ & $\begin{array}{c}\text { Area of green } \\
\text { spaces per 1000 } \\
\text { people }\end{array}$ & $\begin{array}{c}\text { Share of public green } \\
\text { spaces in the area of the } \\
\text { district }\end{array}$ \\
\hline \multicolumn{1}{|c|}{1} & 2 & 3 & 4 \\
\hline Admiralteysky & 15 & 16 & 6 \\
\hline Vasileostrovsky & 17 & 17 & 10 \\
\hline Vyborgsky & 3 & 6 & 1 \\
\hline Kalininsky & 6 & 12 & 5 \\
\hline Kirovsky & 8 & 9 & 17 \\
\hline Kolpinsky & 11 & 7 & 14 \\
\hline Krasnogvardeysky & 10 & 15 & 15 \\
\hline Krasnoselsky & 4 & 5 & 18 \\
\hline Kronshtadtsky & 16 & 10 & 11 \\
\hline Kurortny & 14 & 2 & 7 \\
\hline Moskovsky & 9 & 8 & 2 \\
\hline Nevsky & 13 & 14 & 3 \\
\hline Petrogradsky & 7 & 4 & 12 \\
\hline Petrodvortsovy & 1 & 1 & 16 \\
\hline Primorsky & 5 & 11 & 4 \\
\hline Pushkinsky & 2 & 3 & 13 \\
\hline Frunzensky & 12 & 13 & \\
\hline Centralny & 18 & 18 & \\
\hline Based & & & \\
\hline
\end{tabular}

*Based on [28].

Stage I. Ranking of Saint Petersburg districts by the Indicators "public Park area" and "public green space area per 1000 people".

The rating of Saint Petersburg districts based on the ratio of the indicators "area of public parks" and "area of public green spaces per 1000 people" allows us to assess the level of differentiation of territories according to the degree of greening that provides the reference needs of the population. The results of clustering districts are shown below (table 2).

Table 2. Matrix of ratings of Saint Petersburg districts by the level of provision of public green spaces and public parks for the population*.

\begin{tabular}{|c|c|c|c|}
\hline \multirow{2}{*}{$\begin{array}{l}\text { Ranking based } \\
\text { on the "Public } \\
\text { Park area" } \\
\text { indicator» }\end{array}$} & \multicolumn{3}{|c|}{$\begin{array}{c}\text { Rating based on the indicator "area of public green spaces per } 1000 \\
\text { people» }\end{array}$} \\
\hline & $1-6$ & $7-12$ & 13-18 \\
\hline $1-6$ & $\begin{array}{c}\text { Vyborgsky, } \\
\text { Krasnoselsky, } \\
\text { Petrodvortsovy, } \\
\text { Pushkinsky }\end{array}$ & Kalininsky, Primorsky & - \\
\hline $7-12$ & Petrogradsky & $\begin{array}{l}\text { Kirovsky, Kolpinsky, } \\
\text { Moskovsky }\end{array}$ & $\begin{array}{l}\text { Krasnogvardeysky, } \\
\text { Frunzensky }\end{array}$ \\
\hline $13-18$ & Kurortny & Kronshtadtsky & $\begin{array}{c}\text { Admiralteysky, } \\
\text { Vasileostrovsky, Nevsky, }\end{array}$ \\
\hline
\end{tabular}




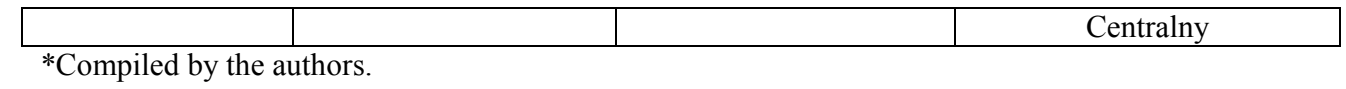

Stage II. Ranking of Saint Petersburg districts by indicators "area of public parks" and "share of public green spaces in the area of the district".

A study on the differentiation of districts given the relative ratio of green spaces and Plaza area and the increased square public Park in every district of the city allow us to estimate the relative level of greening the area and accessibility for the population of large public green spaces (tab. 3).

Table 3. Matrix of ratings of Saint Petersburg districts by the level of greening and accessibility of public green spaces and public parks*.

\begin{tabular}{|c|c|c|c|}
\hline \multirow{2}{*}{$\begin{array}{l}\text { Ranking by the } \\
\text { indicator "Area of } \\
\text { public parks» }\end{array}$} & \multicolumn{3}{|c|}{$\begin{array}{c}\text { Ranking according to the indicator "share of public green spaces in the } \\
\text { area of the district» }\end{array}$} \\
\hline & $1-6$ & $7-12$ & $13-18$ \\
\hline $1-6$ & $\begin{array}{l}\text { Kalininsky, } \\
\text { Petrodvortsovy }\end{array}$ & $\begin{array}{l}\text { Vyborgsky, } \\
\text { Krasnoselsky, } \\
\text { Primorsky }\end{array}$ & Pushkinskiy \\
\hline $7-12$ & $\begin{array}{c}\text { Kirovsky, } \\
\text { Petrogradsky, } \\
\text { Frunzensky }\end{array}$ & Moskovsky & $\begin{array}{l}\text { Kolpinsky, } \\
\text { Krasnogvardeysky }\end{array}$ \\
\hline $13-18$ & Admiralteysky & $\begin{array}{l}\text { Vasileostrovsky, } \\
\text { Nevsky }\end{array}$ & $\begin{array}{l}\text { Kronshtadtsky, } \\
\text { Kurortny, Centralny }\end{array}$ \\
\hline
\end{tabular}

*Compiled by the authors.

\section{Conclusions}

Based on the results of the study, it was concluded that there was a significant differentiation of Saint Petersburg districts as of the beginning of 2020 in terms of the ratio of the absolute indicator of the area of public parks and the relative indicators of greening of the area of districts and the provision of public green spaces to the population.

The results of ranking by the indicators "area of public parks" and "area of public green spaces per 1000 people" allowed us to distinguish three groups of districts.

First group. The rating for the indicator "Public Park area" and the rating for the indicator "area of public green spaces per 1000 people" are the same - the districts of Admiralteysky, Vasileostrovsky, Vyborgsky, Kirovsky, Kolpinsky, Krasnoselsky, Moscow, Nevsky, Petrodvortsovy, Pushkinsky, Centralny.

Second group. The rating for the indicator "Public Park area" is higher than the rating for the indicator "area of public green spaces per 1000 people" - Kalininsky, Krasnogvardeysky, Primorsky, Frunzensky districts.

Third group. The rating for the indicator "area of public green spaces per 1000 people" is higher than the rating for the indicator "Area of public parks" - Petrogradsky, Kronshtadtsky, Kurortny districts.

Third group. The rating for the indicator "area of public green spaces per 1000 people" is higher than the rating for the indicator "Area of public parks" - Petrogradsky, Kronshtadtsky, Kurortny districts.

According to the results of ranking according to the indicators "Area of public parks" and "Share of public green spaces in the area of the district", three groups of districts were identified.

First group. The rating for the Indicator "public Park area" and the rating for the indicator "share of public green spaces in the area of the district" coincide for the Kalininsky, Kronshtadtsky, Kurortny, Moscowsky, Petrodvortsovy and Centralny districts. 
Second group. The rating for the indicator "Public Park area" is higher than the rating for the indicator "share of public green spaces in the area of the district" in the following districts: Vyborgsky, Kolpinsky, Krasnogvardeysky, Krasnoselsky, Primorsky, Pushkinsky.

Third group. The rating for the indicator "share of public green spaces in the area of the district" is higher than the rating for the indicator "Area of public parks" in the districts: Admiralteysky, Vasileostrovsky, Kirovsky, Nevsky, Petrogradsky, Frunzensky.

According to the results of the study, it was revealed that the method proposed by the authors allows identifying the least green areas, formulating measures to increase the level of greening of territories, and forming a spatial development strategy that considers the needs of the population in a comfortable life support environment.

\section{References}

1. Hertzberg L. Ya. Quality of the urban environment: problems of design and implementation 2(24), 29-33 (2013)

2. Research on the effectiveness of healthcare in cities around the world. PwC research (2018) www.pwc.ru//issledovanie-effectivnosti-zdravoohraneniya-v-gorodah-mira.pdf.

3. Th. Stadelbauer, Megacities as conflict-prone spaces

4. N.A. Sluki, Global city: theory and reality (Avanglion LLC, Moscow, 2007)

5. L.Ya. Hertzberg, Quality of the urban environment: problems of design and implementation 1(23), 28-32 (2013)

6. B.S. Istomin, V.A. Filin, Industrial and civil construction 12, 36-39 (2006)

7. D.O. Dushkova, D. Haase, A.V. Evseev, Ecology of urbanized territories 4, 21-27 (2015)

8. S.C. Brown, T. Perrino, J. Lombard, K. Wang, M. Toro, T. Rundek et al., International Journal of Environmental Research and Public Health 15 (2018) DOI: 10.3390/ijerph15030430

9. A. Dzhambov, T. Hartig, I. Markevych, B. Tilov, D. Dimitrova, Environmental Research 160, 47-59 (2018) DOI: 10.1016/j.envres.2017.09.015

10. E. Chivian, A. Bernstein, Sustaining Life: How Human Health Depends on Biodiversity (Oxford University Press, New York, 2008)

11. M.V. Borisov, N.V. Bakaeva, I.V. Chernyaeva, Vestnik MGSU 15(2), 212-222 (2020) DOI: 10.22227/1997-0935.2020.2.212-222.

12. N.I. Barsukova, E.V. Fomina, Bulletin of the Orenburg state University 5(180), 115120 (2015)

13. A.E. Enin, T.I. Grosheva, Construction and reconstruction 4(72), 101-109 (2017)

14. N.V. Bakaeva, I.V. Chernyaeva, Construction and reconstruction 2(76), 85-94 (2018)

15. T. Orlovskaya, S. Ershova, E3S Web of Conferences 135, 03054 (2019) doi.org/10.1051/e3sconf/201913503054

16. S.A. Yershova, Standards of urban Planning design. Experience of Saint Petersburg (2014)

17. A.T. Kearney, Global Cities (2016) https://www.atkearney.com/researchstudies/global-cities-index

18. A.T. Kearney, Global Cities. 2017: Leaders in a world of disruptive innovation (2017) https://www.atkearney.com/documents/10192/12610750/Global+Cities+2017++Leade 
rs + in $+\mathrm{a}+$ World + of + Disruptive+Innovation.pdf/c00b71dd-18ab-4d6b-8ae6$526 \mathrm{e} 380 \mathrm{~d} 6 \mathrm{cc} 4$

19. The Economist Intelligence Unit: Global Liveability Report (A free overview) (2017) https://www.eiu.com/public/topical_report.aspx?campaignid=Liveability17

20. Globalization and World Cities (GaWC) https://www.lboro.ac.uk./gawc/index.html

21. QoL Survey J. Monocle 105, 46 - 69 (2017)

22. Mercer: Vienna tops Mercer's 19th Quality of Living ranking (2017) https://www.mercer.com/newsroom/2017-quality-of-living-survey.html

23. European Commission: Quality of life in European cities (2015) http://www.ec.europa.eu/regional_policy/sources/docgener/studies/pdf/urban/survey20 15_en.pdf

24. D. Savageu, Places Rated Almanac: The classic guide for finding your best places to live in America (Places Rated Books, 2007)

25. P. Taylor, World city network: A global urban analysis (Routledge, London, 2004)

26. P.J. Taylor, B. Derruder, World City Network: A Global Urban Analysis (Routledge, London \& New-York, 2016)

27. P. Hall, The World Cities (Palgrave, New-York, 1966)

28. L. Budd, Urban Studies 35, 663-685 (1998)

29. Yu.K. Bakey, S.A. Yershova, Atlas Saint Petersburg: urban planning and economy (St. Petersburg state University "NIPC of the General Plan of St. Petersburg", SPb. 2019)

30. Saint Petersburg'2019. Summary of statistics (Petrostat, SPb, 2020) 